\title{
A review of sub tidal kelp forests in Ireland: from first descriptions to new habitat monitoring techniques
}

\author{
Kathryn Schoenrock ${ }^{1}$, Kenan Chan ${ }^{1}$, Tony O'Callaghan ${ }^{2}$, Rory O'Callaghan ${ }^{2}$, Aaron \\ Golden $^{1}$, Stacy Krueger-Hadfield ${ }^{3}$, and Anne Marie Power ${ }^{1}$ \\ ${ }^{1}$ NUI Galway \\ ${ }^{2}$ Seasearch Ireland \\ ${ }^{3}$ University of Alabama at Birmingham
}

April 28, 2020

\begin{abstract}
Aim Kelp forests worldwide are important marine ecosystems that foster high primary to secondary productivity and multiple ecosystem services. These ecosystems are increasingly under threat from extreme storms, changing ocean temperatures, harvesting, and greater herbivore pressure at regional and global scales, necessitating urgent documentation of their historical to present day distributions. Species range shifts to higher latitudes have already been documented in some species that dominate subtidal habitats within Europe. Very little is known about kelp forest ecosystems in Ireland, where rocky coastlines are dominated by Laminaria hyperborea. In order to rectify this substantial knowledge gap, we compiled historical records from an array of sources to present historical distribution, kelp and kelp forest recording effort over time, and present rational for the monitoring of kelp habitats to better understand ecosystem resilience. Location Ireland (Northern Ireland and Éire). Methods Herbaria, literature from the Linnaean society dating back to late 1700s, journal articles, government reports, and online databases were scoured for information on L. hyperborea. Information about kelp ecosystems was solicited from dive clubs and citizen science groups that are active along Ireland's coastlines. Results Data were used to create distribution maps, analyse methodology and technology used to record L. hyperborea presence and kelp ecosystems within Ireland. We discuss the recent surge in studies on Irish kelp ecosystems and fauna associated with kelp ecosystems that may be used as indicators of ecosystem health and suggest methodologies for continued monitoring. Main Conclusions While there has been a steady increase in recording effort of the dominant subtidal kelp forest species, L. hyperborea, only recently have studies begun to address other important eco-evolutionary processes at work in kelp forests including connectivity among kelp populations in Ireland. Further monitoring, using suggested methodologies, is required to better understand the resilience of kelp ecosystems in Ireland.
\end{abstract}

\section{Introduction}

Large subtidal brown algal species form extensive underwater forests along the Irish coastline. Dominant species include the orders Fucales (Himanthalia elongata (Linnaeus) S.F. Gray 1821 and Cystoseira spp.), Tilopteridales (Sacchoriza polyschides(Lightfoot) Batters), and Laminariales (Laminaria digitata(Hudson) J.V. Lamouroux, Alaria esculenta (Linnaeus) Greville,Saccharina latissima (Linnaeus) C.E. Lane, C. Mayes, Druehl \& G.W. Saunders, and L. hyperborea (Gunnerus) Foslie). Recently, non-native species have arrived in these subtidal ecosystems via poleward distribution shifts (e.g., Laminariales - L. ochroleucaBachelot de la Pylaie; Schoenrock et al., 2019) or from aquaculture and/or shipping practices (Fucales - Sargassum muticum (Yendo) Fensholt 1955; Laminariales - Undaria pinnatifida (Harvey) Suringar; Kraan, 2017). Along semiexposed rocky coastlines, L. hyperborea forms dense forests, whereas in the calmer, shallow regions of tidal loughs and fjords, S. latissima can form small forests on hard substratum. The paucity of subtidal research makes it difficult to determine the current and historical scope of these habitats along Ireland's shorelines, but the synergistic threats of ocean warming and increased commercial harvesting present a critical need to 
better understand the historical and present day distribution of these important species in order to protect current and future marine forests.

As ecosystem engineers (Jones et al., 1994), kelp provides structure for shallow marine habitats as a resource and a habitat for many organisms ( $>300$ macrofauna species in L. hyperborea forests in Ireland throughout the year; K. Schoenrock et al., personal communication). In other parts of Europe, kelp forests are foraging habitats for marine birds and fish (Norderhaug et al., 2003; 2005), provide substrata for diverse marine assemblages (Bengtsson et al., 2012; H. Christie et al., 2007; H. P. Christie et al., 2003; Norderhaug et al., 2002; K. Schoenrock et al., personal communication), and are the basis of multiple food chains from coastal habitats to the deep sea (Filbee-Dexter et al., 2018), even providing a carbon resource for phytoplankton (Fredriksen, 2003). These habitats can also dampen wave energy, protecting coastlines from erosion (Lovas \& Tørum, 2001), and modify parameters of the marine environment, including carbonate chemistry and light attenuation (Dean, 1985; Hofmann et al., 2011; Krause-Jensen et al., 2015). In Ireland, observations indicate kelp forests are seasonal homes to commercial species like the edible crab (Cancer pagurus Linnaeus), European lobster (Homarus gammarus Linnaeus) and multiple species of juvenile fish that inhabit the kelp canopy (Schoenrock et al., personal communication). There are natural seasonal patterns in these marine communities, but certain species inhabit kelp forests throughout the year including echinoderms, such as the common star ( $<3 \mathrm{~cm}$ in diameter, Asterias rubens Linnaeus), spiny sea star (Marthasterias glacialisJullien), the common urchin (Echinus esculentus Linnaeus), a full summary of species is provided in Table 1, (K. Schoenrock et al., personal communication). The constant presence of these taxa in kelp forests over two years of monitoring suggests that they are indicators of healthy ecosystems in the west of Ireland. Regions to the north, south, and east have similar communities (K. Schoenrock, personal communication), but these regions have not been as thoroughly surveyed as the west of Ireland.

Kelp forest decline has been observed world-wide driven by warming oceans and heatwave events, anthropogenic inputs (harvesting and eutrophication), and herbivore pressure (Krumhansl et al., 2016; Reed et al., 2016; T. Wernberg et al., 2019). In Europe, the distribution of kelp species has changed over time with climate forcing (from the last glacial maximum), and species are predicted to continue retracting their southern range and move northwards with ocean warming (Assis et al., 2016; Assis, Araújo, et al., 2018; Assis, Serrão, et al., 2018a). Currently, warmer-water subtidal forests dominated by L. ochroleuca have retracted from their southern range edges in Morocco to current limits mid-Portugal (Assis, Serrão, et al., 2018b), while the cold-water kelp L. hyperborea has retracted its southern range edge from the Portuguese coastline to the Spanish coastline of the Bay of Biscay (Assis, Araújo, et al., 2018). Marine forests from the Mediterranean coast to southern Portugal are poorly understood, though it seems many species ranges are retracting at their lower latitude range limits. On the other hand, at higher latitudes abundances of some species, such as S. latissima and $S$. polyschides, are increasing at their northern range edges, while the spread of invasive species, such as $U$. pinnatifida, is increasing (Araujo et al., 2016). In addition, herbivore pressure is devastating L. hyperborea at its northern ranges (northern Norway), though urchin populations can fluctuate from year to year, allowing regrowth of some populations (Hagen, 1995). Harvesting is also a threat to kelp forests across Europe, particularly France and Norway where the commercial exploitation of L. hyperborea and $L$. digitata has been occurring for decades (Valero et al., 2001). The mechanical removal of $L$. hyperborea results in the removal of whole individuals. Recovery can take greater than five years (Lorentsen et al., 2010), and populations in the heaviest areas of harvest may be important reservoirs of genetic diversity (e.g., Brittany, France: Robuchon et al., 2014).

Kelp have been of great interest in the past, in flux with economic, socio-political, and technical advances beginning during the 1700s. Therefore, there are many historical accounts of seaweed from sea captains, fisheries, and naturalists along the Irish coastline from the late 1700s to the present day. These qualitative historical records provide perspective on the value of kelp along Ireland's coastline, but given the pressures outlined above, we need a better understanding and documentation of kelp ecosystems. In this review, we focus on the presence of the subtidal species L. hyperborea from 1700s Ireland to present day, collating disparate historical records for the first time. This review significantly contributes to our understanding of kelp forest function in Ireland at a time when interest in kelp harvesting is increasing despite the fact 
we do not understand basic ecological and evolutionary processes at work in these systems. We show that regular and systematic monitoring is urgently needed in order to conserve and inform policy makers to foster resilience, defined as the ability to recover from a disturbance and maintain ecosystem function, in this vital coastal resource.

\section{Laminaria hyperborea records in Ireland}

In November 2019, the written records of phycologists and old texts were accessed in the Linnaean Society of London to investigate the study of $L$. hyperborea from 1700 to present day. National herbaria were visited to examine kelp voucher specimens from Ireland over the same time period, though we must note that there are, in general, very few records of large brown algae in these herbaria: National University of Ireland Galway (M. Guiry, 1 record, Finavarra County Clare), The National Botanic Gardens of Ireland (2 records, Clifden County Galway), Trinity College (0 records), and Natural History Museum of London (3 records, Clare Island). The lack of voucher specimens is likely due to the difficulty in preserving thick thalli on paper and many specimens were likely jellied rather than pressed for preservation (Tsuda \& Abbott, 1985). Precise collection details were not noted on many herbarium sheets making it difficult to ascertain the location of collection, therefore herbarium data were not included when mapping kelp records along the coastline through time. Site records for L. hyperborea were downloaded or donated from the Global Biodiversity Information Facility (January10th, 2020, gbif.org), Ocean Biogeographic Information System (January 10 ${ }^{\text {th }}$, 2020, obis.org), National Biodiversity Data Centre (September $19^{\text {th }}, 2019$, biodiversityireland.ie), and the Environmental Protection Agency (September 17 ${ }^{\text {th }}, 2019$ ). All data were concatenated, and quality filtered for duplicate records (i.e., same coordinates, same date) and correct geographical location (i.e., points on land were removed). Data were then sorted by year of recording and number of years recorded to highlight sites accessed earliest within the country ('period of first record'; Figure 1) and of great interest ('number of years recorded'; Figure 2). Overall, recording effort increased as we approach the present day, with a boom in the 1990s, however few sites were recorded multiple times (Table 2).

Records for kelp forests were provided through recreational Comhairle Fo-Thuinn (CFT) dive clubs throughout the country, the BIOMAR data set (Picton \& Morrow, 2006), and recent Irish Research Council and Environmental Protection Agency projects (K. Schoenrock, personal communication), and these were analysed separately as the distribution of kelp ecosystems (not just individual kelp sightings or drift algae). Kelp ecosystems (including survey data) have significantly fewer records (Figure 3) in comparison to kelp records (Figure 1), however there is some overlap. We hope that future observations of L. hyperboreawill include more metadata, such as whether the kelp was found in situ, and whether it was in a kelp forest, park, or other habitat, or on a strandline (as beach wrack). The difference between a kelp forest or park is generally described as a reduced density of large kelp individuals, generally adjacent to a kelp forest, although there is no ecological distinction to date (Parr, 2020).

\section{Historical Records, 1700-1900}

During the 1700s, many natural historians began extensive descriptions of what were termed 'the Algae' from the initial growth to fructification (formation of reproductive structures) in intertidal species (Greville, 1830 and authors listed within). Some of these researchers focused on seaweeds of the British Isles (present day Éire and the United Kingdom), and many were women and clergymen (e.g. Reverend David Landsborough of Glasgow, 1847) who had a keen interest in the natural world (see Table 3). This work may have been driven by the need to understand marine harvest because 'kelp,' potash of all seaweeds, was an economic resource used in agriculture, as packaging material, and an iodine resource (Harvey, 1849), and this is certainly a driver for renewed interest in seaweeds from the 1940s (Ara Mara; South \& Titley, 1986) to today (Monagail \& Morrison, 2020). Cultural uses of kelp were also observed: one herbarium record from The National Botanic Gardens of Ireland is a rosary made from the stipes of L. digitata collected from Glencolumbkille, County Donegal (Figure 4). Historical records of Irish or Irish-based phycologists is very thoroughly outlined in Guiry (2012); but unfortunately, the information does not define the distribution of any recorded seaweeds, but instead refers to zonation on the shoreline (e.g., the taxon now termed $S$. latissima was thought to only live between high and low tides).Laminaria spp. and other seaweeds were often described as tangles (Harvey, 
1849), and herbarium records in The National Botanic Gardens of Ireland and Trinity College indicated many Laminaria spp. could easily be grouped into what was Laminaria phyllis (present dayL. digitata) which Harvey noted as having multiple ecotypes, some of which are actually L. hyperborea (Harvey, 1841). Previous names (not misnomers) for L. hyperborea include Fucus hyperboreus Gunnerus, Fucus scoparius Strom 1762, Hafgygia cloustonii (Edmondston) Areschoug, 1883, Laminaria cloustoniEdmondston, Laminaria hyperborea f. compressa Foslie, 1884 (Guiry \& Guiry, 2020).

Marine algal communities in the British Isles were originally described as dominated by 'Olive series' (Phaeophyta), with many red algae (3/8 of species) and greens (1/4 species: Harvey, 1849). Interesting notes on the ecology of seaweeds include seaweed support of food webs and community structure: "The Algae, therefore by supporting the base, support the structure" (Harvey, 1849), which is potentially the first description of seaweeds as ecosystem engineers and/or providing ecosystem services. Observations were also noted on ecological interactions between coralline algae and fleshy algae (Lamouroux, 1826), the annual phenology (annual growth patterns) of marine algae, variation in zonation from subtidal to intertidal ('land flora') across regions, and the distribution of dominant brown algae (Cocks, 1859; Harvey, 1849). Most of these studies were restricted to coastlines where seaweed could be easily observed. Cocks (1859) even notes his thought that there would be little space for seaweed below the tidelines (i.e., subtidal). There could be a good deal of data on subtidal marine algae in sounding records of the British Admiralty dating back to 1580 which would have refuted this idea; however, these records were and are not easily accessible. Up to the $20^{\text {th }}$ century much of phycology in Ireland was focused on species descriptions and distributions to the extent of providing 'presence' data on certain portions of the coastlines (broadly noted as 'Northern Ireland' or 'County Cork' for example) which is still an issue with some reports today (see Scally et al., 2020).

\section{Historical Records, 1900-2018}

Some of the first comprehensive surveys of natural environments occurred on Lambay and Clare Island in the early 1900s, and these multidisciplinary reports provide a comparison of intertidal algal communities between 1910 to the 1990s (Cotton, 1909; 1912), but more recent surveys have collected subtidally, expanding the flora record for these locations (Rindi \& Guiry, 2004). Subtidal observations became easier for phycologists with the advent of diving bells and, later, the self-contained underwater breathing apparatus (SCUBA). Jack Kitching first described methods for studying sublittoral ecology in the UK using a diving helmet in the 1930s, which subsequently led to the first observation of the species associations in Laminaria spp. forests, including the dominance of L. hyperborea (formerlyL. cloustoni ; Kitching et al., 1934). He later brought that equipment to Ireland where he intensively studied the ecology of Lough Hyne (or Ine) with generations of students, providing the basis for kelp forest ecology in this region of the world which would later be proliferated by Joanna Kain (Jones) using SCUBA from 1960 - late 1980. The seaweeds of Lough Hyne were first described by Rees (1931), later followed up by Maggs et al. (1983) who also contributed to many reports on the biotope 'kelp forests' in Ireland and the UK (Birkett et al., 1998; Maggs et al., personal communication). Kain's work defined $L$. hyperborea' s population dynamics (Kain, 1963), reproduction (Kain \& Jones, 1964), competition and growth (Creed et al., 1998; Kain, 1969; 1962; 1976a; 1977), and description of succession and subcanopy/understory seaweeds (Kain, 1976b; 1982; 1989). This research, alongside that of Norwegian and French phycologists, forms the basis of our understanding of kelp forest ecology in Ireland (summarised in Kelly, 2005), though more recent research projects in the UK and Ireland aim to supplement this knowledge base with modern data (e.g. Burrows et al., 2014; K. Schoenrock et al., personal communication).

The first distribution record with multiple georeferenced data points of large seaweeds in the UK and Ireland was published by Crisp and Southward in 1958, as a side note to their record of intertidal invertebrates (Crisp \& Southward, 1958). From 1950 to 1990 multiple studies referenced seaweeds in specific regions (see Table 3), for instance Morton (1994) noted the abundance of marine algae in Northern Ireland by county. The BIOMAR survey (Picton \& Morrow, 2006) of marine habitats across Ireland summarised species associated with subtidal kelp forest habitats in the 1990s using SACFOR abundance scales for taxa (super abundant, abundant, common, frequent, occasional, and rare) that could be repeated over time in the same locations. This was followed by a repeat survey of regions in Crisp \& Southward (1958) by Simkanin et al. (2005) 
which highlighted increases or declines of species abundance over the 45 years between studies. Declines in northerly species in these intertidal habitats occurred in five of 12 species (including $L$. hyperborea and S. latissima ) while increases occurred in one of 12 species (invasive barnacle Australminius modestus ; Simkanin et al., 2005). In contrast, one of nine southerly species declined in abundance, despite the trend in Europe for southerly species to expand their northern ranges (e.g., L. ochroleuca : Schoenrock et al., 2019; Smale et al., 2015). Merder et al. (2018) later showed that community similarity indices in Simkanin et al. (2005)'s data were more influenced by the environmental variables wave energy and Chla concentration than sea or air temperature, which resulted in differences in communities from east to west coasts. The formation of Seasearch Ireland in 2009 has boosted records of subtidal habitats, to the scale that most recent L. hyperborea records in Ireland are supplied by citizen scientists (2010-2018, Figure 1). The remaining data is from research agencies like the Environmental Protection Agency or National Parks and Wildlife Services.

BIOMAR data are unique in the fact that they can be analysed to highlight the impact that kelp species and region have on faunal assemblages within kelp ecosystems (Table $4 \& 5$ ). Species SACFOR scales were given a numerical value $(0=$ absent, $1=$ rare, $2=$ occasional, $4=$ frequent, $5=$ common, $6=$ abundant, and $7=$ super abundant) for each site record and a Bray-Curtis similarity matrix was created with species data across sites, finally similarity of species compositions within kelp forests a) within the same geographical region (Table 4) and b) within forests dominated by different kelp species (Table 5) were evaluated using an analysis of similarity (ANOSIM; Clarke \& Gorley, 2006). Regional differences were apparent in kelp communities, for example more species contribute to community similarity in kelp forests in west Ireland than in other regions (Table 4). Dominant kelp species also affected community assemblages, but too few replicates exist in mixed and A. esculenta forests to define species driving differences (Table 5). When compared with a recent study in the west of Ireland (Table 1), species associated with L. hyperborea forests are notably different (Table 5 ), potentially due to the quantitative vs. qualitative data collection methodology, and survey focus. For instance, kelp blades where many hydroids reside (e.g., Electra pilosa, Table 4 \& 5) were not included in the swath surveys used for community analysis in K. Schoenrock et al. (personal communication). Moving forward, creating a standard monitoring methodology would benefit analysis of data and highlight [changing] patterns in species distribution and habitat usage over time.

In summary, distribution records for kelp have fluctuated over time in terms of recording effort and regions visited. The focus of study has progressed from basic species description and use as a resource from the 1700s - 1910s, expanding to disciplines like ecology, evolution and natural product chemistry which are facilitated by technology (Young et al., 2015). Present-day investigations utilise species distribution models to project future distributions of seaweeds based on the habitat suitability or environmental forcing associated with records of species presence. Yesson et al. (2015a) modelled the distribution of kelp and fucoid species in the UK and Ireland using data from herbaria and online databases and found (i) most distribution data comes from studies after 1970 (in contrast to the present review where the majority were post-1990) and (ii) different environmental requirements for each species. Non-natives, like U. pinnatifida, are found in areas with high average temperatures (but also restricted to man-made or modified structures, e.g. harbours), while the native A. esculenta is found in regions with colder average temperatures (Yesson et al., 2015a) and is thought to be more susceptible to temperature than the Laminaria spp. of the region (Müller et al., 2009).Laminaria spp. are influenced more by substrate type than temperature or light in current distributions, and L. hyperboreais thought to cover $48,654 \mathrm{~km}^{2}$ of coastline in the UK and Ireland, specifically on rocky substrate with moderate wave exposure (Yesson et al., 2015a). Species distribution models indicate that $L$. hyperborea blankets all coastlines in Ireland that are not adjacent to major freshwater sources (see Figure 5 in Yesson et al., 2015a), though this potentially overestimates its distribution along the east coast because the coastline has more sand/mud/marsh habitats than rocky coastline (Neilson \& Costello, 1999). More interestingly, the study also indicates regions suitable for species range expansions including Bellmullet County Mayo, where the first record of L. ochroleuca in Ireland was noted in 2018 (Schoenrock et al., 2019). Models that factor in climate change predictions show kelps retracting northward (Assis et al., 2016), and this has already been noted in species found in Ireland (Simkanin et al., 2005; Yesson et al., 2015b). These findings indicate the need for better habitat mapping tools, which are superior to point records, but also difficult to achieve with species 
in the sublittoral where remote sensing and monitoring require significant investment of resources.

\section{Resilience and monitoring of Laminaria hyperboreacommunities}

Recovery of kelp ecosystems after large disturbances is an important aspect of resilience in the marine environment. Laminaria hyperborea is a long lived species, reaching 15 years of age in west Ireland (maximum of 18 years in Finnmark, Norway; Sjøtun et al., 1993) but with an average age of 4 years, where juvenile kelps reappear throughout the year as canopy is removed by storms, regenerating the populations annually (Schoenrock et al., personal communication). There is no destructive grazing in L. hyperboreacommunities in this region. The common urchin, Echinus esculentus, does not destructively graze gametophytes or juvenile sporophytes in the sub-canopy, and generally adult kelps are left untouched (Sjotun et al., 2006). Another urchin species (Paracentrotus lividus ) was overfished in the $20^{\text {th }}$ century (Barnes \& Crook, 2001), and small populations of the green urchin (Strongylocentrus droebachiensis ) do not pose a threat in Ireland as they do in Norway and urchin populations generally do in other regions of the world (Estes \& Duggins, 1995; Hagen, 1995; Ling et al., 2015). The blades of L. hyperborea annually regenerate, starting growth in winter and reaching maximum length mid-summer, and producing sori from October to March (Kain \& Jones, 1964). The zoospores produced within sori disperse $\sim 200 \mathrm{~m}$ and settle to develop into gametophytes and following fertilization, juvenile sporophytes (Fredriksen et al., 1995). This life cycle may facilitate resilience of kelp populations, allowing for refuge from environmental and biological stressors as either (i) a large sporophyte is too large for grazers or (ii) a microscopic stage is safe from storms or otherwise that would uproot large sporophytes (i.e., bet-hedging: Lubchenco \& Cubit, 1980). However, our understanding of the role of kelp gametophytes as a spore bank is limited to only a handful of studies (e.g., Robuchon, Couceiro, et al., 2014).

Resilience may also be conferred through genetic diversity as genetic variation is the essential evolutionary mechanism with which species can respond to environmental stochasticity. Larger, outcrossed populations tend to be more genetically diverse, than smaller, often inbred, populations. Studying these patterns in the sea can be challenging as not all predictions from terrestrial environments necessarily apply (i.e., chaotic genetic patchiness: Galindo et al., 2006; Selkoe et al., 2010). Population genetic tools provide a powerful way with which to study how genetic diversity is partitioned in natural populations, and by extension, patterns of connectivity and population structure in the sea (seaweed population genetics reviewed in Krueger-Hadfield \& Hoban, 2016; Valero et al., 2011). Myriam Valero et al. (2011) reviewed the current state of the literature on population genetic patterns in kelp, with most of the studies centred on kelps in Europe (mainly in France [Brittany] and Portugal), Australia, Chile, and California. Interestingly, species that had population genetic data (Macrocystis pyrifera, Lessonia nigrescens, and L. digitata) harboured the highest levels of diversity in areas with strong harvesting pressure. Population connectivity (with kelp species) is largely affected by habitat discontinuity (e.g. Billot et al., 2003), and patterns of isolation by distance are common (e.g. Robuchon, Le Gall, et al., 2014). Understanding how genetic diversity is partitioned and how populations are connected to one another is a necessity in order to determine how populations could recover from harvesting (Robuchon, Le Gall, et al., 2014) or from disturbances, such as heatwaves seen within the Pacific Ocean (Wernberg et al., 2019).

Myriam Valero et al. (2011) conclude that "while kelps are economically and ecologically important, only a few studies have attempted to assess genetic variation within kelp populations and on small scales." Likewise, few studies have included temporal scales in monitoring efforts for genetic diversity. This is even more apparent along the coast of Ireland where until recently there were no systematic studies of the population genetics of kelp species. Schoenrock et al. (2019) found that genetic diversity in the non-native L. ochroleuca was comparable to the southern range edge of this species rather than closer populations in France. Moreover, the excess of heterozygotes at Scots Port in Bellmullet was interpreted as the result of recent admixture following a founder event (Schoenrock et al., 2019). In addition, glacial refugia, or areas of longterm persistence during glacial maxima, have been predicted for L. hyperborea along the southern coastline of Ireland (Assis et al., 2016), suggesting these areas may harbour unique genetic diversity. Schoenrock et al. (2020) confirmed that the highest levels of allelic diversity and heterozygosity were found in the L. hyperborea population at Lough Hyne in the southwest of Ireland. They genotyped seven other population along 
the west coast from County Cork to County Donegal and found patterns of decreasing diversity as well as isolation by distance. However, only eight sites spread over much of the west coast of Ireland were included in this study, rendering it difficult to study smaller scale patterns in genetic structure. On-going analysis of forty-two sites along the entire coastline of Ireland should help investigate this further (K. Schoenrock et al., personal communication), with temporal sampling to provide insight into the genetic stability of $L$. hyperborea in Ireland (sensu Valero et al., 2011). Continued monitoring of these genetic resources, as well as expanding the number of taxa included (other canopy species like S. polyschides or S. latissima), will be important moving forward.

Monitoring kelp forest habitats in Ireland is a difficult task, as the reticulated coastline is highly exposed to the dynamic North Atlantic Ocean. A recent survey indicates that healthy kelp ecosystems can be quantified through density and height of the kelp bed, which was quantified using single beam sonar with video validation of species ID (Biosonics; Scally et al., 2020). This technology is incredibly helpful when creating a mapping tool for sub-surface forests, however population surveys from the west of Ireland indicate that density and height of stable kelp forests have huge fluctuations throughout the year (peak in summer) with an average of 20.21 individuals $\mathrm{m}^{-2}$, few of which are canopy forming; greatest kelp height is observed in shallow habitats ( $2 \mathrm{~m}$ depth, LAT; K. Schoenrock, personal communication), although forests reach $\sim 15 \mathrm{~m}$ depth on islands off Ireland's coasts (C. Maggs, personal communication). A better monitoring scheme should be put in place and could include the use of sonar (see Blight et al., 2011; Mac Craith \& Hardy, 2015) or satellite platforms to map these ecosystems. Although more typically used to monitor blooms in estuarine and coastal habitats (Ulvaspp.: Mora-soto et al., 2020), satellite data is also useful in mapping kelp species that span the water column, and was pioneered in the east Pacific (M. pyrifera: Mora-soto et al., 2020; Cavanaugh et al., 2010). Simms \& Dubois (2010) created a method for submerged kelp beds in the north western Atlantic, which could potentially be used on the subtidal L. hyperborea forests in Ireland.

A recent review by Duffy et al. (2019) classifies marine macroalgae and seagrass monitoring as an 'emerging priority' globally for ocean and coastal management. Tiered observation systems are proposed to monitor broadscale patterns at wider intervals, using remote-sensing coupled with underwater observations, but detailed in situ sampling annually at selected sites is also advised, to capture information such as taxonomic associations to bolster data and understanding of ecosystem function (Duffy et al., 2019). Ireland and other small countries are unlikely to devote substantial resources to regular kelp forest monitoring without more apparent delivery of ecosystem services. A foreseeable way to monitor status and trends in these habitats would be to ground-truth remote sensing technology and supplement this effort with citizen scientist observations. Seasearch Ireland provides a scheme for CFT divers to 'adopt a site' and kelp forests could be targeted in their region, documenting the habitats kelp species are found in or form. The presence of associated faunal species abundance, particularly large mobile species that are easier to see (see indicator species in Table 1), would help to create a data set where fluctuations in species assemblages within kelp forests could be monitored, filling key information gaps on the ecosystem services provided by these ecosystems (e.g. Bertocci et al., 2015). National governments should be committed to monitor kelp ecosystems under European Union (EU) environmental legislation (EU Marine Strategy Framework Directive, MSFD (European Commission, 2008), and the EU Water Framework Directive (European Commission, 2000) because ecosystem based management (EBM) is central to the legislations objectives (Berg et al., 2015), including healthy commercial fish and shellfish stocks (MSFD descriptor 3) and healthy marine food webs (MSFD descriptor 4).

\section{Conclusions}

Studies of kelp forests in Ireland are historically rare and contain mostly qualitative information. Kelp records with georeferenced data points date back to 1913 and continued over the decades, with a pulse in records from the 1990s onward. Most records are single sightings, indicating that, either people do not record multiple sightings of the same kelp forest or many regions are not revisited. Recording effort should move towards documenting kelp ecosystems (presence of a forest) as well as abundance of 'indicator species' within using standardised methodology. This would boost evidence that kelp forests are indicators of good environmental 
status and could be used operationalise MSFD legislation. Maintaining resilience of kelp forests and their associated species is important not only for the ecosystems, but the services they provide to civilisation, which can be achieved through monitoring habitats and management of stressors (Krumhansl et al., 2016). Development of a remote sensing mapping tool (via satellite or otherwise) would aid in monitoring the distribution kelp forests distributions.

\section{References}

Araujo, R. M., Assis, J., Aguillar, R., Airoldi, L., Barbara, I., Bartsch, I., Bekkby, T.,... Sousa-Pinto, I. (2016). Status, trends and drivers of kelp forests in Europe: an expert assessment.Biodiversity and Conservation , 25, 1319-1348. https://doi.org/10.1007/s10531-016-1141-7

Assis, J., Araújo, M. B., \& Serrão, E. A. (2018). Projected climate changes threaten ancient refugia of kelp forests in the North Atlantic. Global Change Biology , 24(1), e55-e66. https://doi.org/10.1111/gcb.13818

Assis, J., Lucas, A. V., Bárbara, I., \& Serrão, E. Á. (2016). Future climate change is predicted to shift longterm persistence zones in the cold-temperate kelp Laminaria hyperborea . Marine Environmental Research , 113, 174-182. https://doi.org/10.1016/j.marenvres.2015.11.005

Assis, J., Serrão, E. Á., Coelho, N. C., Tempera, F., Valero, M., \& Alberto, F. (2018a). Projected climate changes threaten ancient refugia of kelp forests in the North Atlantic. Global Change Biology, 24(1), e55-e66. https://doi.org/10.1111/gcb.13818

Assis, J., Serrão, E. Á., Coelho, N. C., Tempera, F., Valero, M., \& Alberto, F. (2018b). Past climate changes and strong oceanographic barriers structured low-latitude genetic relics for the golden kelpLaminaria ochroleuca . Journal of Biogeography , 45(10), 2326-2336. https://doi.org/10.1111/jbi.13425

Barnes, D. K. A., \& Crook, A. C. (2001). Implications of temporal and spatial variability in Paracentrotus lividus populations to the associated commercial coastal fishery. In Burnell, G. (Eds), Coastal Shellfish - A Sustainable Resource. Developments in Hydrobiology, (vol 160, pp. 95-102). Springer, Dordrecht.

Bengtsson, M. M., Sjøtun, K., Lanzén, A., \& Øvreås, L. (2012). Bacterial diversity in relation to secondary production and succession on surfaces of the kelp Laminaria hyperborea . ISME Journal , 6, 2188-2198. https://doi.org/10.1038/ismej.2012.67

Berg, T., Fürhaupter, K., Teixeira, H., Uusitalo, L., \& Zampoukas, N. (2015). The Marine Strategy Framework Directive and the ecosystem-based approach - pitfalls and solutions. Marine Pollution Bulletin ,96 (1-2), 18-28. https://doi.org/10.1016/j.marpolbul.2015.04.050

Bertocci, I., Araújo, R., Oliveira, P., \& Sousa-Pinto, I. (2015). Potential effects of kelp species on local fisheries. Journal of Applied Ecology , 52(5), 1216-1226. https://doi.org/10.1111/1365-2664.12483

Billot, C., Engel, C. R., Rousvoal, S., Kloareg, B., \& Valero, M. (2003). Current patterns, habitat discontinuities and population genetic structure: The case of the kelp Laminaria digitata in the English channel. Marine Ecology Progress Series , 253. 111-121 https://doi.org/10.3354/meps253111

Birkett, D. A., Maggs, C. A., Dring, M. J., \& Boaden, P. J. S. (1998).Infralittoral Reef Biotopes with Kelp Species (volume VII). An overview of dynamic and sensitivity characteristics for conservation management of marine SACs .

Blight, A., Foster-Smith, R., Sotheran, I., Egerton, J., McAllen, R., \& Savidge, G. (2011). Development of a Methodology for the Quantitative Assessment of Ireland's Inshore Kelp Resource Marine Research SubProgramme (NDP 2007-'13) Series . www.marine.ie.

Burrows, M. T., Smale, D., O'Connor, N., Van Rein, H., \& Moore, P. (2014). Developing indicators of good environmental status for UK kelp habitats. JNCC Report No. 525, SAMS/MBA/Q . www.jncc.defra.gov.uk 
Cavanaugh, K. C., Siegel, D. A., Kinlan, B. P., \& Reed, D. C. (2010). Scaling giant kelp field measurements to regional scales using satellite observations. Marine Ecology Progress Series , 403, 13-27. https://doi.org/10.3354/meps08467

Christie, H., Jørgensen, N. M., \& Norderhaug, K. M. (2007). Bushy or smooth, high or low; importance of habitat architecture and vertical position for distribution of fauna on kelp. Journal of Sea Research , 58(3), 198-208. https://doi.org/10.1016/j.seares.2007.03.006

Christie, H. P., Jörgensen, N. M., Norderhaug, K. M., \& Waage-Nielsen, E. (2003). Species distribution and habitat exploitation of fauna associated with kelp (Laminaria hyperborea) along the Norwegian coast. Journal of the Marine Biological Association of the United Kingdom , 83, 687-699.

Clarke, K. R., \& Gorley, R. N. (2006). PRIMER v6: User Manual/Tutorial (Plymouth Routines in Multivariate Ecological Research). PRIMER-E.

Cocks, J. (1859). Observations on the growth and time of appearance of some of the marine algae, \&c. Botanical Journal of the Linnean Society , 4(15), 101-105.

Cotton, A. D. (1909). Marine Algae of the West of Ireland Author.Bulletin of Miscellaneous Information Royal Botanic Gardens, Kew) , 7, 312-315.

Cotton, A. D. (1912). Marine Algae: Clare Island Survey- Part 15 .

Creed, J. C., Kain, J. M., \& Norton, T. A. (1998). An experimental evaluation of density and plant size in two large brown seaweeds. Journal of Phycology , 34(1), 39-52. https://doi.org/10.1046/j.1529-8817.1998.340039.x

Crisp, D. J., \& Southward, A. J. (1958). The distribution of intertidal organisms along the coasts of the English Channel. Journal of the Marine Biological Association of the United Kingdom , 37(1), 157-203.

Dean, T. A. (1985). The temporal and spatial distribution of underwater quantum irradiation in a southern California kelp forest.Estuarine, Coastal and Shelf Science , 21(6), 835-844.

Duffy, J. E., Benedetti-Cecchi, L., Trinanes, J., Muller-Karger, F. E., Ambo-Rappe, R., Boström, C., Buschmann, A. H., ... Yaakub, S. M. (2019). Toward a coordinated global observing system for seagrasses and marine macroalgae. Frontiers in Marine Science , 6, 317. https://doi:10.3389/fmars.2019.00317

Estes, J. A., \& Duggins, D. O. (1995). Sea Otters and Kelp Forests in Alaska : Generality and Variation in a Community Ecological Paradigm.Ecological Monographs, 65(1), 75-100. https://doi.org/10.2307/2937159

European Commission, 2000. Directive 2000/60/EC of the European Parliament and of the Council of 23 October 2000 establishing a framework for Community actions in the field of water policy. Official Journal of the European Communities L327, 1. 22.12.2000.

European Commission, 2008. Directive 2008/56/EC of the European Parliament and of the Council of 17 June 2008 establishing a framework for Community actions in the field of marine environmental policy (Marine Strategy Framework Directive). Official Journal of the European Communities L164/19 25.06.2008.

Ferreira, J. G., Andersen, J. H., Borja, A., Bricker, S. B., Camp, J., Cardoso da Silva, M., Garces, E., ... Claussen, U. (2011). Overview of eutrophication indicators to assess environmental status within the European Marine Strategy Framework Directive. Estuarine, Coastal and Shelf Science, 93(2), 117-131. https://doi.org/10.1016/j.ecss.2011.03.014

Filbee-Dexter, K., Wernberg, T., Norehaug, K. M., Ramirez-Llodra, E., \& Pedersen, M. F. (2018). Movement of Pulsed Resource Subsidies from kelp forests to deep fjords. Oecologia , 187(1), 291-304.

Fredriksen, S. (2003). Food web studies in a Norwegian kelp forest based on stable isotope ( $\delta 13 \mathrm{C}$ and $\delta$ $15 \mathrm{~N})$ analysis. Marine Ecology Progress Series, 260, 71-81.

Fredriksen, S., Sjøtun, K., Lein, T. E., \& Rueness, J. (1995). Spore dispersal in Laminaria hyperborea (Laminariales, Phaeophyceae).Sarsia , 80(1), 47-54. https://doi.org/10.1080/00364827.1995.10413579 
Galindo, H. M., Olson, D. B., \& Palumbi, S. R. (2006). Report Seascape Genetics: A Coupled OceanographicGenetic Model Predicts Population Structure of Caribbean Corals. Current Biology , 16(16), 1622-1626. https://doi.org/10.1016/j.cub.2006.06.052

Greville, R. K. (1830). Algae Britannicae, or descriptions of the marine or other inarticulated plants of the British Islands, belonging to the order Algae. Maclachlan \& Stewart.

Guiry, M.D., \& Guiry, G. M. (2020). AlgaeBase . World-Wide Electronic Publication, National University of Ireland, Galway. https://www.algaebase.org

Guiry, Michael D. (2012). A catalogue of Irish seaweeds . Koeltz Scientific books.

Hagen, N. T. (1995). Recurrent destructive grazing of successionally immature kelp forests by green sea urchins in Vestsfjorden, northern Norway. Marine Ecology Progress Series , 123(1-3), 95-106. https://doi.org/10.3354/meps12

Harvey, W.H. (1849). A Manual of the British Marine Algae. John van Voort, Paternaster Row.

Harvey, William H. (1841). A manual of the British marine algae:containing generic and specific descriptions of all the known British species of sea-weeds, and of confervae, both marine and fresh-water, . London,.

Hofmann, G. E., Smith, J. E., Johnson, K. S., Send, U., Levin, L. A., Micheli, F., Paytan, A., ... Martz, T. R. (2011). High-frequency dynamics of ocean pH: A multi-ecosystem comparison. PLoS ONE ,6 (12). https://doi.org/10.1371/journal.pone.0028983

Jones, C. G., Lawton, J. H., \& Shachak, M. (1994). Organisms as Ecosystem Engineers. In Ecosystem Management (pp. 130-147). Springer New York. https://doi.org/10.1007/978-1-4612-4018-1_14

Kain, J. M. (1962). Aspects of the biology of Laminaria hyperborea I. Vertical Distribution. Journal of the Marine Biological Association of the United Kingdom , 42, 377-385.

Kain, J. M. (1963). Aspects of the biology of Laminaria hyperborea II. Age, weight and length. Journal of the Marine Biological Association of the United Kingdom , 43, 129-151.

Kain, J. M. (1969). The Biology of Laminaria hyperborea . V. Comparison with early stages of competitors. Journal of the Marine Biological Association of the United Kingdom, 49(02), 455. https://doi.org/10.1017/s0025315400036031

Kain, J. M. (1976a). The biology of Laminaria hyperborea IX. Growth pattern of fronds. Journal of the Marine Biological Association of the United Kingdom , 56, 603-628.

Kain, J. M. (1976b). The biology of Laminaria hyperborea VIII. Growth on cleared areas. Journal of the Marine Biological Association of the United Kingdom , 56, 267-290.

Kain, J. M. (1977). The biology of Laminaria hyperborea X. The effect of depth on some populations. Journal of the Marine Biological Association of the United Kingdom , 57, 587-607.

Kain, J. M. (1982). The reproductive phenology of nine species of Rhodophyta in the subtidal region of the Isle of Man. British Phycological Journal , 17(3), 321-331. https://doi.org/10.1080/00071618200650321

Kain, J. M. (1989). The seasons in the subtidal. British Phycological Journal , 24(3), 203-215. https://doi.org/10.1080/0007161

Kain, J. M., \& Jones, N. S. (1964). Aspects of the biology ofLaminaria hyperborea III. survival and growth of gametophytes.Journal of the Marine Biological Association of the United Kingdom , 44(2), 415-453. https://doi.org/10.1017/S0025315400024929

Kelly, E. (2005). The Role of Kelp in the Marine Environment Irish Wildife Manuals No. 17.

Kitching, J. A., Machan, T. T., \& Gilson, H. C. (1934). Studies in Sublittoral Ecology. I. A Submarine Gully in Wembury Bay, South Devon.Journal of the Marine Biological Association of the United Kingdom , 19(2), 677-705. https://doi.org/10.1017/S0025315400046713 
Kraan, S. (2017). Undaria marching on; late arrival in the Republic of Ireland. Journal of Applied Phycology , 29(2), 1107-1114. https://doi.org/10.1007/s10811-016-0985-2

Krause-Jensen, D., Duarte, C. M., Hendriks, I. E., Meire, L., Blicher, M. E., Marbà, N., \& Sejr, M. K. (2015). Macroalgae contribute to nested mosaics of $\mathrm{pH}$ variability in a sub-Arctic fjord. In Biogeosciences Discussions . https://doi.org/10.5194/bgd-12-4907-2015

Krueger-Hadfield, S. A., \& Hoban, S. M. (2016). The importance of effective sampling for exploring the population dynamics of haploid-diploid seaweeds. Journal of Phycology , 52(1), 1-9. https://doi.org/10.1111/jpy.12366

Krumhansl, K. A., Okamoto, D. K., Rassweiler, A., Novak, M., Bolton, J. J., Cavanaugh, K. C., Connell, S. D., ... Byrnes, J. E. K. (2016). Global patterns of kelp forest change over the past half-century.PNAS , 113(48), 13785-13790. https://doi.org/10.1073/pnas.1606102113

Lamouroux, P. M. (1826). Memoire sur la Geogrraphie des plantes marines.Annales Des Sciences Naturelles $, 7,60-82$.

Ling, S. D., Scheibling, R. E., Rassweiler, A., Johnson, C. R., Shears, N., Connell, S. D., Salomon, A. K., ... Johnson, L. E. (2015). Global regime shift dynamics of catastrophic sea urchin overgrazing.Philosophical Transactions of the Royal Society B: Biological Sciences , 370(1659), 1-10. https://doi.org/10.1098/rstb.2013.0269

Lorentsen, S. H., Sjøtun, K., \& Grémillet, D. (2010). Multi-trophic consequences of kelp harvest. Biological Conservation , 143, 2054-2062. https://doi.org/10.1016/j.biocon.2010.05.013

Lovas, S. M., \& Tørum, A. (2001). Effect of the kelp Laminaria hyperborea upon sand dune erosion and water particle velocities. Coastal Engineering , 44, 37-63.

Lubchenco, J., \& Cubit, J. (1980). Heteromorphic life histories of certain marine algae as adaptations to variations in herbivory.Ecology , 61(3), 676-687. https://doi.org/10.2307/1937433

Mac Craith, E., \& Hardy, D. (2015). Inishbofin Kelp Mapping Study-Preliminary Report in Mapping Kelp Distribution (Issue September).

Maggs, C. A., Freamhainn, M. T., \& Guiry, M. D. (1983). A Study of the Marine Algae of Subtidal Cliffs in Lough Hyne (Ine). Proceedings of the Royal Irish Academy. Section B: Biological, Geological, and Chemical Science, 83, 251-266.

Maggs, C. A., Guiry, M. D., \& Dring, M. J. (personal communication). Subtidal algal zontation and light penetration off the Aran Islands, Galway Bay, Ireland.

Merder, J., Freund, J. A., Meysick, L., Simkanin, C., O'Riordan, R. M., \& Power, A. M. (2018). East-west spatial groupings in intertidal communities, environmental drivers and key species. Journal of the Marine Biological Association of the United Kingdom , 98(2), 423-435. https://doi.org/10.1017/S0025315416001442

Monagail, M. Mac, \& Morrison, L. (2020). The seaweed resources of Ireland : a twenty-first century perspective. Journal of Applied Phycology . https://doi.org/10.1007/s10811-020-02067-7

Mora-Soto, A., Palacios, M., Macaya, E. C., Gomez, I., Huovinen, P., Perez-Matus, A., Young, M., ... Macias-Fauria, M. (2020). A high-resolution global map of Giant kelp (Macrocystis pyrifera) forests and intertidal green algae (Ulvophyceae) with Sentinel-2 imagery. Remote Sensing , 12(4), 1-20. https://doi.org/10.3390/rs1204069

Morton, O. (1994). Marine Algae of Northern Ireland, vii. 123p. Ulster Museum Publication no. 271, Belfast.

Muller, R., Laepple, T., Bartsch, I., \& Wiencke, C. (2009). Impact of oceanic warming on the distribution of seaweeds in polar and cold-temperate waters. Botanica Marina , 52(6), 617-638. https://doi.org/10.1515/BOT.2009.080

Neilson, B., \& Costello, M. J. (1999). The relative lengths of seashore substrate around the coastline of Ireland as determined by digital methods in a Geographical Information System. Estuarine, Coastal E5 Shelf Science, 49, 501-508. 
Norderhaug, K. M., Christie, H., Fossa, J. H., \& Frederiksen, S. (2005). Fish-macrofauna interactions in a kelp (Laminaria hyperborea) forest. Journal of the Marine Biological Association of the United Kingdom, 85(5), 1279-1286.

Norderhaug, K. M., Christie, H., \& Rinde, E. (2002). Colonisation of kelp imitations by epiphyte and holdfast fauna; a study of mobility patterns. Marine Biology , 141(5), 965-973. https://doi.org/10.1007/s00227-0020893-7

Norderhaug, K. M., Fredriksen, S., \& Nygaard, K. (2003). Trophic importance of Laminaria hyperborea to kelp forest consumers and the importance of bacterial degredation to food quality. Marine Ecology Progress Series , 255, 135-144.

Parr, J. (2020). Marine Life Survey Data (collected by volunteers) collated by MarLIN. MarLIN, Collated Marine Life Survey Datasets .

Picton, B. E., \& Morrow, C. C. (2006). BioMar Survey of marine speceis and habitats of Ireland. Ulster Museum, Belfast.

Reed, D., Washburn, L., Rassweiler, A., Miller, R., Bell, T., \& Harrer, S. (2016). Extreme warming challenges sentinel status of kelp forests as indicators of climate change. Nature Communications , 7, 1-7. https://doi.org/10.1038/ncomms13757

Rees, T. K. (1931). Preliminary Observations on the Phaeophyceae of Lough Hyne ( Ine ). Journal of Ecology , 19(2), 439-448.

Rindi, F., \& Guiry, M. D. (2004). A long-term comparison of the benthic algal flora of Clare Island, County Mayo, western Ireland.Biodiversity and Conservation , 13, 471-492.

Robuchon, M., Couceiro, L., Peters, A. F., Destombe, C., \& Valero, M. (2014). Examining the bank of microscopic stages in kelps using culturing and barcoding. European Journal of Phycology , 49(1), 128-133. https://doi.org/10.1080/09670262.2014.892635

Robuchon, M., Le Gall, L., Mauger, S., \& Valero, M. (2014a). Contrasting genetic diversity patterns in two sister kelp species co-distributed along the coast of Brittany, France. Molecular Ecology, 23(11), 2669-2685. https://doi.org/10.1111/mec.12774

Scally, L., Pfieffer, N., \& Hewitt, E. (2020). The monitoring and assessment of six EU habitats directive Annex I Marine Habitats. Irish Wildlife Manuals, No. 118. National Parks and Wildlife Service, Department of Culture, Hertitage and the Gaeltacht, Ireland. ISSN 1393 - 6670

Schoenrock, K. M., O'Callaghan, R., O'Callaghan, T., \& Stengel, D. B. (personal communication). A modern ecological baseline forLaminaria hyperborea forests in the Republic of Ireland. Submitted to Limnology and Oceanography .

Schoenrock, K. M., O'Callaghan, T., O'Callaghan, R., \& Krueger-Hadfield, S. A. (2019). First record of non-nativeLaminaria ochroleuca Bachelot de la Pylaie in Ireland found in Beal an Mhuirthead, County Mayo. Marine Biodiversity Records , 12(1), 9.

Selkoe, K. A., Watson, J. R., White, C., Horin, T. Ben, Iacchei, M., Mitarai, S., Siegel, D. A., Gaines, S. D., \& Toonen, R. J. (2010). Taking the chaos out of genetic patchiness: Seascape genetics reveals ecological and oceanographic drivers of genetic patterns in three temperate reef species. Molecular Ecology , 19(17), 3708-3726. https://doi.org/10.1111/j.1365-294X.2010.04658.x

Simkanin, C., Power, A. M., Myers, A., McGrath, D., Southward, A., Mieszkowska, N., Leaper, R., \& O'Riordan, R. (2005). Using historical data to detect temporal changes in the abundances of intertidal species on Irish shores. Journal of the Marine Biological Association of the United Kingdom , 85(6), 13291340 . 
Simms, E. L., \& Dubois, J. M. M. (2010). Satellite remote sensing of submerged kelp beds on the Atlantic coast of Canada. International Journal of Remote Sensing , 22(11), 2083-2094.

Sjotun, K., Christie, H., \& Fossa, J. H. (2006). The combined effect of canopy shading and sea urchin grazing on recruitment in kelp forest (Laminaria hyperborea ). Marine Biology Research , 2(1), 24-32.

Sjotun, K., Fredriksen, S., Lein, T. E., Rueness, J., \& Sivertsen, K. (1993). Population studies of Laminaria hyperborea from its northern range of distribution in Norway. In A. R. . Champman, M. T. Brown, \& M. Lahaye (Eds.), Fourteenth International Seaweed Symposium, Developments in Hydrobiology, (vol 85 pp. 215-221). Springer.

Smale, D. A., Wernberg, T., Yunnie, A. L. E., \& Vance, T. (2015). The rise of Laminaria ochroleuca in the Western English Channel (UK) and comparisons with its competitor and assemblage dominantLaminaria hyperborea . Marine Ecology , 36(4), 1033-1044. https://doi.org/10.1111/maec.12199

South, G. R., \& Titley, I. (1986). Checklist and distributional index of the benthic marine algae of the North Atlantic Ocean .

Tsuda, R. T., \& Abbott, I. A. (1985). Collection, handling, preservation, and logistics. In Linttler M.M. \& Littler, D. S. (Eds) Handbook of Phycological Methods. Ecological Field Methods: Macroalgae. (v4, pp. 67-86). Cambridge, Cambridge University Press.

Valero, M., Engel, C., Billot, C., Kloareg, B., \& Destombe, C. (2001). Concepts and issues of population genetics in seaweeds. Cahiers de Biologie Marine , 42(1-2), 53-62.

Valero, M., Destombe, C., Mauger, S., Ribout, C., Engel, C. R., Daguin-Thiebaut, C., \& Tellier, F. (2011). Using genetic tools for sustainable management of kelps: A literature review and the example ofLaminaria digitata. Cahiers de Biologie Marine , 52(4), 467-483.

Wernberg, T., Krumhansl, K., Filbee-Dexter, K., \& Pedersen, M. F. (2019). Status and trends for the world's kelp forests. In World Seas: An Environmental Evaluation. (pp. 57-78). Academic Press.

Yesson, C., Bush, L. E., Davies, A. J., Maggs, C. A., \& Brodie, J. (2015a). The distribution and environmental requirements of large brown seaweeds in the British Isles. Journal of the Marine Biological Association of the United Kingdom , 95(4), 669-680. https://doi.org/10.1017/S0025315414001453

Yesson, C., Bush, L. E., Davies, A. J., Maggs, C. A., \& Brodie, J. (2015b). Large brown seaweeds of the british isles: Evidence of changes in abundance over four decades. Estuarine, Coastal and Shelf Science, 155, 167-175. https://doi.org/10.1016/j.ecss.2015.01.008

Young, R. M., Schoenrock, K. M., von Salm, J. L., Amsler, C. D., \& Baker, B. J. (2015). Structure and function of macroalgal natural products. In Stengel, D. \& Connan, S. (Eds), Natural Products From Marine Algae: Methods and Protocols, Methods in Molecular Biology, (vol. 1308, pp39-73). Springer https://doi.org/10.1007/978-1-4939-2684-8_2

\section{Data Accessibility}

All data used within this manuscript is freely available in National Herbaria and online databases: obis.org, gbif.org, biodiversityireland.ie, and erc.epa.ie/droplet/.

\section{Tables}

Table 1. A list of 'indicator species' that are consistently associated with healthy Laminaria hyperborea forests throughout the year, including their average abundance per $\mathrm{m}^{-2}$ of kelp forest and trophic function (K. Schoenrock et al., personal communication). A lack of these species within a L. hyperboreaforest may indicate 1) the ecosystem is unhealthy or 2) the habitat is small ('kelp park' see Parr, 2020) or comprised of mixed kelps (see Table 5 where communities change with kelp species). 


\begin{tabular}{lll}
\hline Species & Average Abundance $\mathbf{~ m}^{\mathbf{2}}$ & Trophic function \\
\hline Sponge, encrusting Suberites spp. & 0.26 & Filter feeder \\
Hydroid, Obelia geniculata & 0.27 & Filter feeder (on kelp) \\
Anemone, Urticina felina & 1.54 & Predator \\
Cnidarian, Caryophyllia smithii & 0.59 & Filter feeder \\
Annelid, Eupolymnia nebulosa & 0.02 & Filter feeder \\
Crustacean, Palaemon serratus & 0.016 & Predator \\
Mollusc, Gibbula umbilicalis & 0.86 & Grazer \\
Mollusc, Gibbula cineraria & 0.06 & Grazer \\
Echinoderm, Asterias rubens $(<3 \mathrm{~cm}$ diameter) & 1.22 & Predator \\
Echinoderm, Marthasterias glacialis & 0.41 & Predator \\
Echinoderm, Holothuria forskali & 0.39 & Suspension feeder \\
Echinoderm, Echinus esculentus & 0.2 & Grazer \\
Ascidian, Aplidium punctum & 0.78 & Filter feeder \\
Ascidian, Distomus variolosus & 4.99 & Filter feeder \\
Ascidian, Diplostoma spongiforme & 0.08 & Filter feeder \\
Vertebrate, Pomatoschistus spp. & 0.015 & Predator \\
Vertebrate, Gobiusculus flavescens & 0.39 & Predator \\
\hline
\end{tabular}

Table 2. The number of Laminaria hyperborea records for a site grouped by time period from pre-1950 to 2018 (present day).

\begin{tabular}{llllllll}
\hline & $<\mathbf{1 9 5 0}$ & $\mathbf{1 9 5 0 - 6 9}$ & $\mathbf{1 9 7 0 - 8 9}$ & $\mathbf{1 9 9 0 - 9 9}$ & $\mathbf{2 0 0 0 - 0 9}$ & $\mathbf{2 0 1 0 - 1 8}$ & Total \\
\hline 1 & 0 & 6 & 344 & 558 & 293 & 495 & $\mathbf{1 6 9 6}$ \\
2 & 1 & 3 & 30 & 524 & 26 & 54 & $\mathbf{6 3 8}$ \\
3 & 0 & 4 & 5 & 5 & 2 & 4 & $\mathbf{2 0}$ \\
4 & 0 & 3 & 3 & 0 & 0 & 0 & $\mathbf{6}$ \\
5 & 0 & 1 & 0 & 0 & 0 & 0 & $\mathbf{1}$ \\
6 & 0 & 3 & 0 & 0 & 0 & 0 & $\mathbf{3}$ \\
Total & $\mathbf{1}$ & $\mathbf{2 0}$ & $\mathbf{3 8 2}$ & $\mathbf{1 0 8 7}$ & $\mathbf{3 2 1}$ & $\mathbf{5 5 3}$ & $\mathbf{2 3 6 4}$ \\
\hline
\end{tabular}

Table 3. A list of phycologists and natural historians who worked on seaweed communities in the UK and Ireland from the 1700s to 2010, enabling our understanding of these communities. People are listed with known names or initials, dates of activity specifying life span, date of only phycology publication or first year of publication if still active (noted as 'From...'), and specific information about the phycologist or naturalist (publication information or occupation).

\begin{tabular}{lll}
\hline Name & Year & Record \\
\hline John Templeton & $1766-1825$ & Flora Hibernica, Ulster Museum \\
Dawson Turner & $1775-1858$ & British Phycologist \\
James Lawson Drummond & $1783-1853$ & Irish Phycologist \\
Ellen Hutchins & $1785-1815$ & Irish Phycologist \\
George Crawford Hyndman & $1796-1867$ & Irish Phycologist \\
William Thompson & $1805-1852$ & XXII. Additions to the fauna of Ireland \\
Anne Elizabeth Ball & $1808-1872$ & Irish Phycologist \\
William Henry Harvey & $1811-1866$ & Irish and British Phycologist \\
William McCalla & $1814-1849$ & Naturalist, Roundstone County Galway \\
J. Cocks Esq., M.D. & 1859 & Observations on the growth and time of appearance \\
\end{tabular}




\begin{tabular}{|c|c|c|}
\hline Name & Year & Record \\
\hline Alexander Stewart \& Corry & 1858 & Flora of the north-east of Ireland \\
\hline Robert L. Praeger and Arthur Disbrowe Cotton & 1865-1953 & Irish naturalist, Clare Island surveys \\
\hline Captain Cary (Christian name unknown) & 1869-1912 & Sea Captain, Four marine algae herbaria to Nationa \\
\hline S.O. Gray & 1867 & British seaweeds: an introduction to the study of th \\
\hline E.M. Holmes & 1883 & New British Marine Algae, A revised list of the Brit \\
\hline E.A.L Batters & 1895 & New or critical British marine algae, On some new \\
\hline Henry Hanna & 1898-1899 & Irish Phycologist \\
\hline T.K. Rees & 1935 & The marine algae of Lough Ine \\
\hline M.J. Lynn & 1937 & Notes on the algae of the district of Whiterock, Stra \\
\hline Agnes T. Brennan & 1945 & Notes on the Distribution of Certain Marine Algae \\
\hline W.A.P. Black & 1950 & The seasonal variation in weight and chemical comp \\
\hline M. Parke & From 1950 & British Phycologist \\
\hline H.M. Parkes & 1958 & A general survey of the marine algae of Mulroy Bay \\
\hline Peter S. Dixon & From 1960 & British Phycologist \\
\hline L.H. Colinvaux & 1965 & A partially annotated bibliography of the algae of $\mathrm{I}$ \\
\hline Joanna M. Kain (Jones) & $1930-2017$ & British Phycologist \\
\hline Trevor A. Norton & From 1967 & Irish Phycologist \\
\hline M.J.P Scannell & 1969 & Unpublished Records of marine algae made mainly \\
\hline Michael D. Guiry & From 1969 & Irish Phycologist \\
\hline Colin Pybus & 1975 & Some notes and observations on encrusting red alga \\
\hline Osborne Morton & 1978 & Interesting records of algae from Ireland \\
\hline J.P. Cullinane & From 1966 & Marine Algal Records from the South Coast of Irela \\
\hline Patrick M. Whelan & From 1976 & Marine Algal Records from the South Coast of Irela \\
\hline Mairin de Valera & From 1939 & Littoral and benthic Investigations of the west coast \\
\hline Matthew J. Dring & From 1980 & British Phycologist \\
\hline Linda Mary Irvine & From 1969 & British Phycologist \\
\hline Cilian Roden & 1981 & Noteworthy marine algae from County Dublin \\
\hline Christine A. Maggs & From 1983 & Irish and British phycologist \\
\hline Barry Egan & 1983 & Notes on the marine algae of Ballycotton Bay, Cou \\
\hline Sue Hiscock & From 1982 & British Phycologist \\
\hline Juliet Brodie & From 1988 & British Phycologist \\
\hline Dagmar B. Stengel & From1994 & Irish Phycologist \\
\hline Sammy De Grave & From 2000 & Irish maerl beds \\
\hline Cynthia Trowbridge & From 2001 & Invasive algal species in Ireland \\
\hline Stephan Kraan & From 2000 & Irish Phycologist \\
\hline Fabio Rindi & From 1994 & Molecular species identification \\
\hline Liam Morrison & From 2004 & Irish Phycologist \\
\hline
\end{tabular}

Table 4. ANOSIM analysis of BIOMAR abundance scales for 31 kelp forest sites in 5 regions: southwest (County Cork), southeast (County Wicklow and Wexford), west (County Kerry, Clare, Galway and Mayo, northwest (County Sligo and Donegal), and north (north County Donegal). Similarity of communities in regions, species richness $(\mathrm{S})$, and site number $(\mathrm{N})$ are displayed along with species driving similarity and \% contribution.

\begin{tabular}{lll}
\hline Geographic region & Species & \% Contribution \\
\hline Southwest & Callopora lineata & 51.1 \\
$6.99 \%$ similarity & Crisia denticulata & 14.6 \\
$\mathrm{~S}=31.78$ & Alcyonidium diaphanum & 10.57 \\
$\mathrm{~N}=9$ & Electra pilosa & 7.13
\end{tabular}




\begin{tabular}{lll}
\hline Geographic region & Species & \% Contribution \\
\hline & Scrupocellaria spp. & 7.13 \\
& & \\
Southeast & Flustra foliacea & 32.98 \\
$19.38 \%$ similarity & Electra pilosa & 29.79 \\
$\mathrm{~S}=78$ & Membranipora membranacea & 25.04 \\
$\mathrm{~N}=6$ & Chaetopterus variopedatus & 5.03 \\
& & \\
West & Electra pilosa & 24.7 \\
$11 \%$ similarity & Callopora lineata & 16.72 \\
$\mathrm{~S}=41.15$ & Flustra foliacea & 10.47 \\
$\mathrm{~N}=7$ & Crisia eburnea & 7.97 \\
& Bicellariella ciliata & 5.96 \\
& Parasmittina trispinosa & 5.96 \\
& Chaetopterus variopedatus & 5.9 \\
& Phyllodoce laminosa & 4.47 \\
& (O) Spirorbidae & 4.47 \\
& (O) Terebellidae & 4.47 \\
$\mathrm{Northwest}$ & & \\
$0 \%$ similarity & No data & \\
$\mathrm{S}=50.67$ & & \\
$\mathrm{~N}=6$ & & 11.68 \\
& & \\
North & Electra pilosa & 15.13 \\
$57.07 \%$ similarity & Crisia denticulata & \\
$\mathrm{S}=44$ & Scrupocellaria & \\
$\mathrm{N}=3$ & Flustra foliacea & \\
& &
\end{tabular}

Table 5. ANOSIM analysis of BIOMAR abundance scales for 31 kelp forests composed predominantly of Laminaria hyperborea but 3 sites dominated by Alaria esculenta and 1 mixed kelp forest (L. hyperborea and Saccharina latissima ). $\mathrm{S}$ is species richness, $\mathrm{N}$ is number of sites, and \% contribution of fauna driving similarity within kelp forests

\begin{tabular}{lll}
\hline Kelp species & Species & \% Contribution \\
\hline L. hyperborea & Electra pilosa & 26.68 \\
$13.85 \%$ similarity & Flustra foliacea & 16.51 \\
$\mathrm{~S}=51.74$ & Callopora lineata & 15.44 \\
$\mathrm{~N}=27$ & Membranipora membranacea & 9.35 \\
& Crisia denticulata & 7.17 \\
& Scrupocellaria spp. & 5.91 \\
& Crisia eburnea & 4.14 \\
& Chaetopterus variopedatus & 2.8 \\
& Alcyonidium diaphanum & 2.66
\end{tabular}

L. hyperborea and S. latissima No data

$\mathrm{S}=48$

$\mathrm{N}=1$

A. esculenta

No data 


\begin{tabular}{lcc}
\hline Kelp species & Species & \% Contribution \\
\hline $\mathrm{S}=11$ & & \\
$\mathrm{~N}=3$ & & \\
\hline
\end{tabular}

\section{Figures}

Figure 1. Laminaria hyperborea 'period of first record' for Ireland from pre-1950 (1913 was the only record), from 1950-1969, 1970-1989, 1990-1999, 2000-2009, and 2010 to 2018 (most recent year of record on data platforms).

Figure 2. Recording effort, 'number of years recorded' forLaminaria hyperborea along the coast of Ireland from 1913 to present day.

Figure 3. Records of kelp forest ecosystems from the BIOMAR study (Picton \& Morrow, 2006), IRC and EPA research programs (Schoenrock et al., personal communication) and Comhairle Fo-Thuinn (CFT) dive clubs around Ireland. Many locations overlap with locations from database queries (Figures 1 \& 2), indicating that GBIF and OBIS records could often indicate presence of kelp forests.

Figure 4. Image of a kelp rosary within the herbarium at The National Botanic Gardens of Ireland. The 'beads' of the rosary are likely made from made from the stipes of Laminaria digitata collected from Glencolumbkille, County Donegal.

Figure 1. 


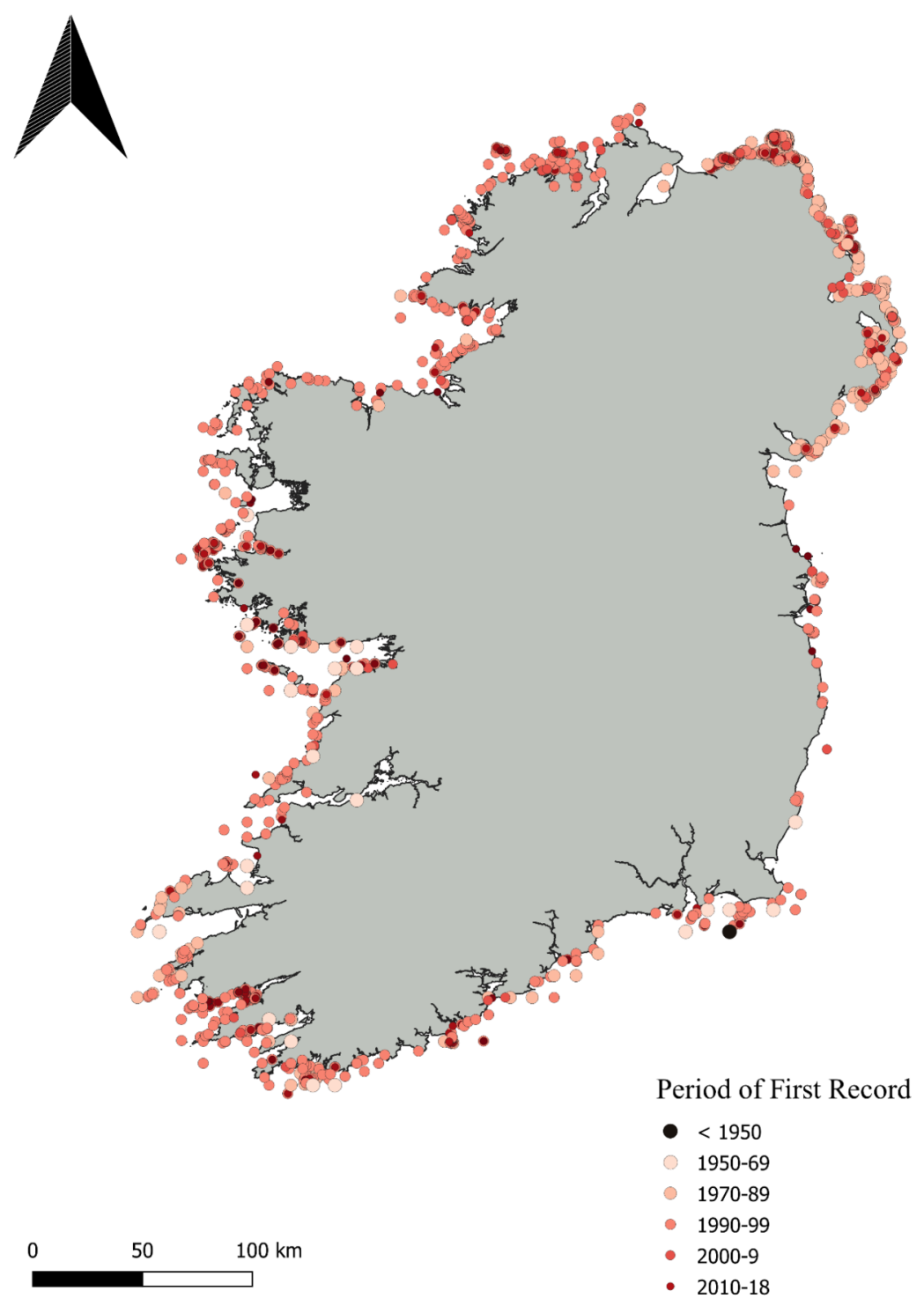

Figure 2. 


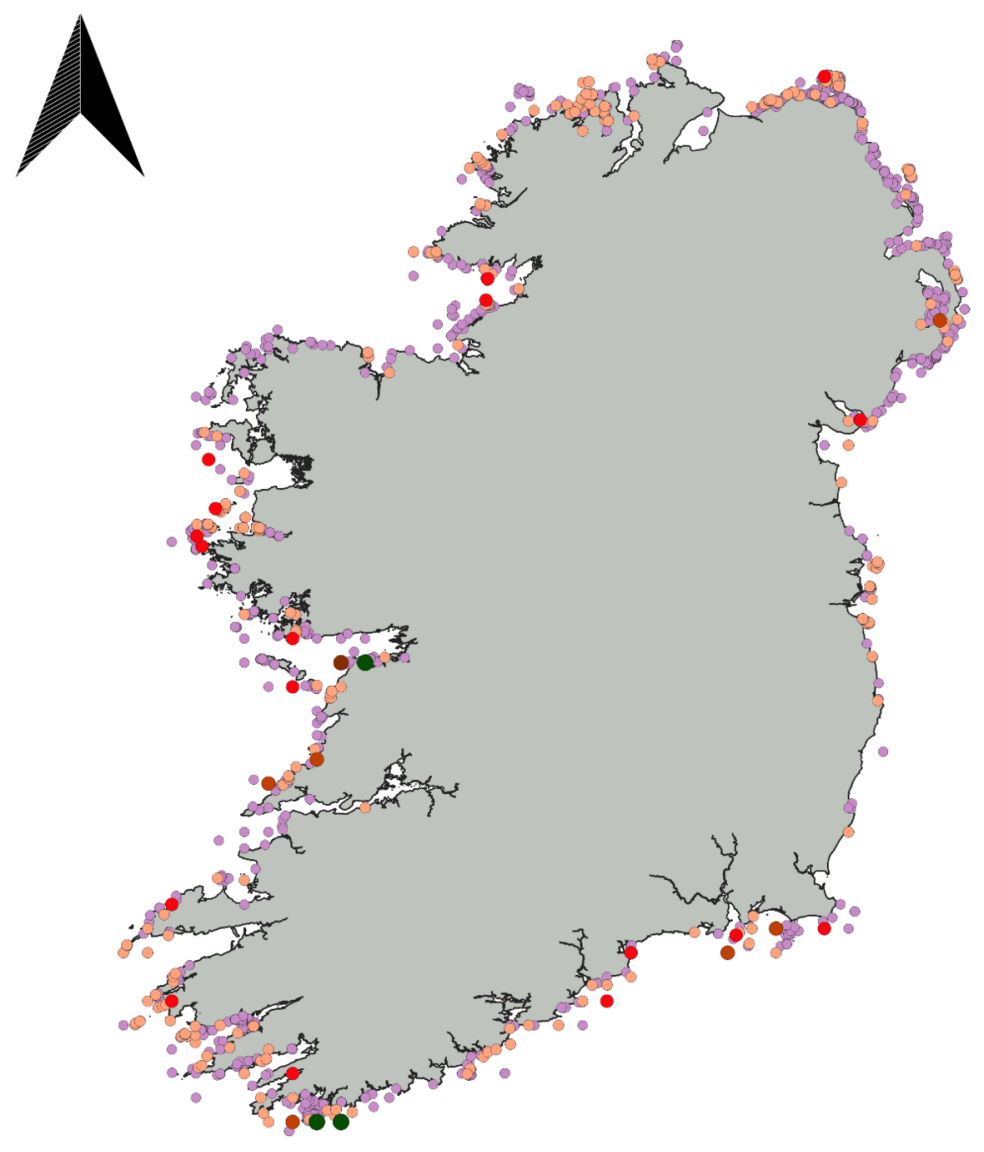

Number of Years Recorded

- 1 record

- 2 records

- 3 records

- 4 records

$0 \quad 50 \quad 100 \mathrm{~km}$

- 5 records

- 6 records

Figure 3. 


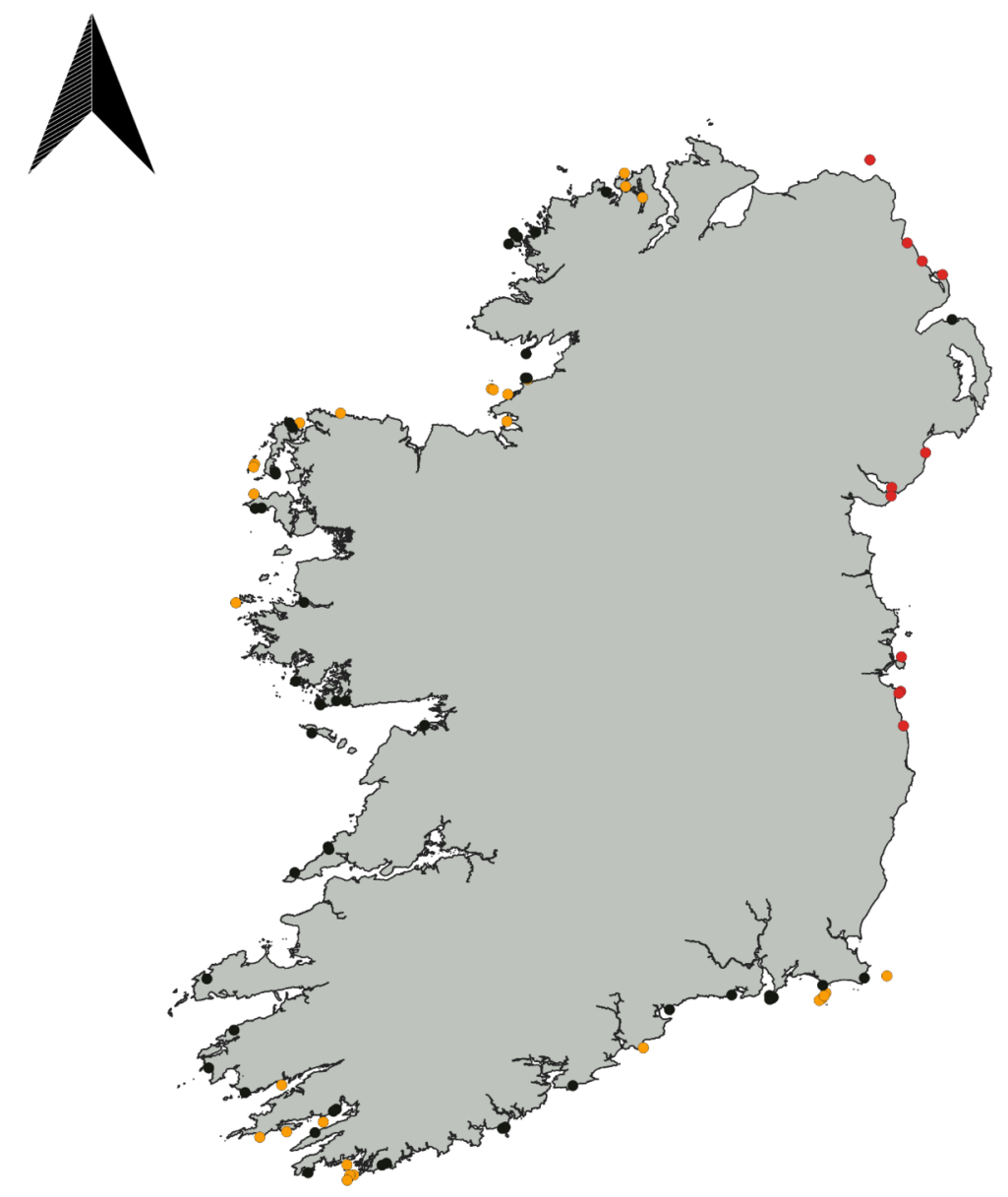

Kelp Ecosystems

- EPA-IRC sites

- CFT sites

- BIOMAR sites

Figure 4. 


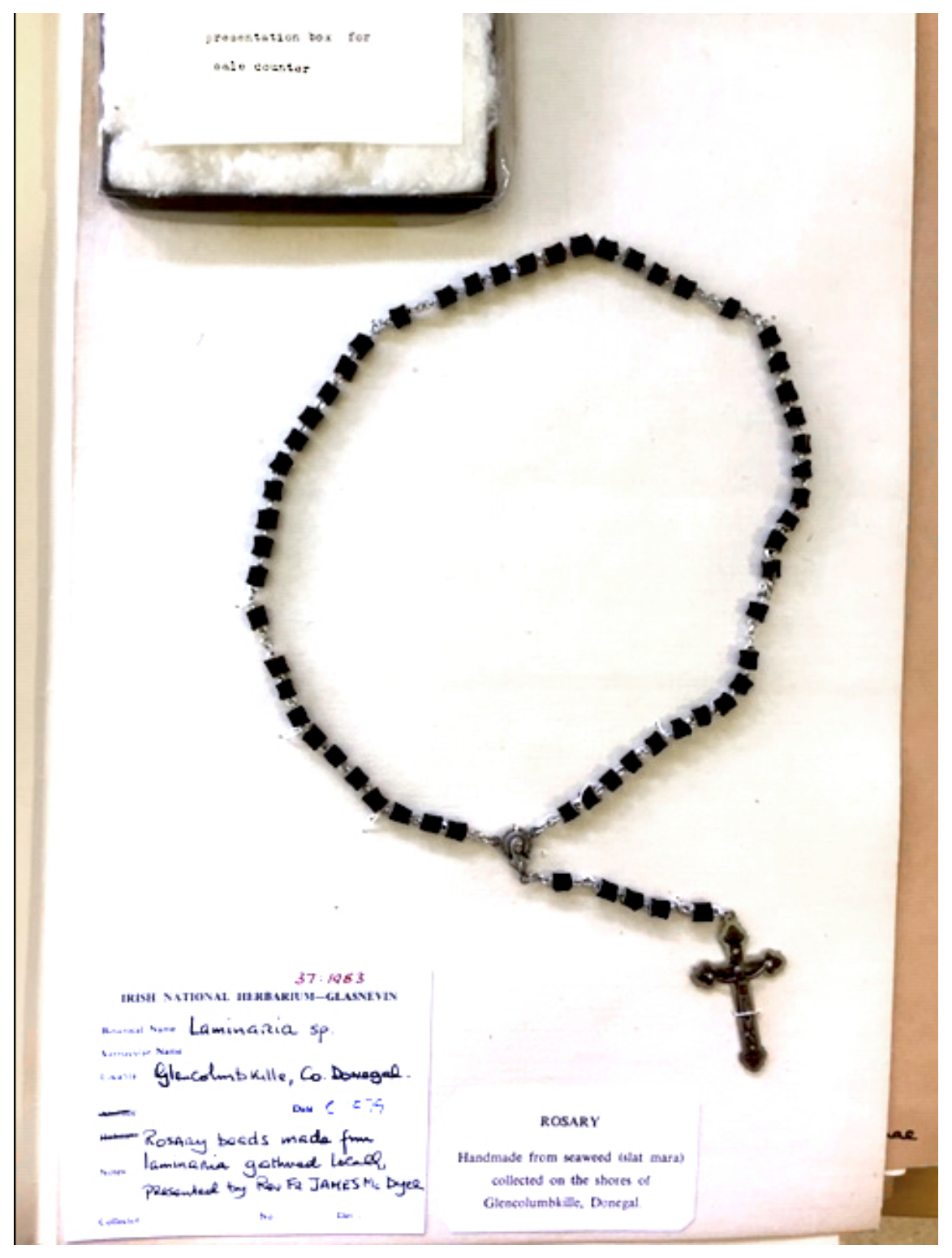

